\title{
MORPHOFUNCTIONAL ECOLOGY OF SEEDLINGS FOUND IN A TROPICAL RAINFOREST SEED BANK, IN THE NORTHEAST OF BRAZIL
}

\author{
Joselane Príscila Gomes da Silva ${ }^{1 *}$, Luiz Calos Marangon², Ana Lícia Patriota Feliciano ${ }^{3}$, Rinaldo Luiz \\ Caraciolo Ferreira $^{4}$ \\ 1*Universidade Federal Rural de Pernambuco, Programa de Pós-Graduação em Ciências Florestais, Recife, Pernambuco, Brasil - \\ joselane.gomess@gmail.com* \\ ${ }^{2}$ Universidade Federal Rural de Pernambuco, Departamento de Ciências Florestais, Recife, Pernambuco, Brasil - luiz.marangon@ufrpe.br \\ ${ }^{3}$ Universidade Federal Rural de Pernambuco, Departamento de Ciências Florestais, Recife, Pernambuco, Brasil - ana.feliciano@ufrpe.br \\ ${ }^{4}$ Universidade Federal Rural de Pernambuco, Departamento de Ciências Florestais, Recife, Pernambuco, Brasil - rinaldo.ferreira@ufrpe.br
}

Received for publication: 07/02/2020 - Accepted for publication: 02/07/2020

\begin{abstract}
Resumo
Ecologia morfofuncional de plântulas encontradas no banco de sementes de floresta tropical úmida, nordeste do Brasil. O objetivo desta pesquisa foi avaliar a composição florística e a identificação de plântulas de espécies arbóreas, sob o ponto de vista da ecologia morfofuncional, localizadas no banco de sementes do solo de um remanescente de Floresta Ombrófila Densa das Terras Baixas, Nordeste do Brasil. Foram retiradas 152 amostras de solo $(0,2 \mathrm{~m} \times 0,15 \mathrm{~m} \times 0,05 \mathrm{~m})$ de um remanescente florestal, armazenadas em sacos de polietileno, identificadas e em seguida levadas para o Viveiro Florestal da Universidade Federal Rural de Pernambuco, onde foram colocadas em caixas de polietileno sob sombrite $70 \%$, avaliadas diariamente por um período de sete meses. As plântulas emergidas foram fotografadas, separadas em morfoespécies, identificadas em nível de família, gênero e, quando possível, em nível de espécie. Estimaram-se a densidade e frequência absoluta, a classificação sucessional e morfológica dos cotilédones das plântulas. Foram registradas 1.577 plântulas de 31 morfoespécies. Melastomataceae foi a família que apresentou maior riqueza com $48 \%$ das espécies identificadas. A densidade média foi 344,62 sementes. $\mathrm{m}^{-2}$ com maiores densidades para espécies da família Melastomataceae, juntamente com Maprounea guianensis e Cecropia palmata. Plântulas com germinação epígeas, fanerocotiledonares e com cotilédones foliáceos predominou com 93,56\%. O banco de sementes foi composto, predominantemente, por espécies pioneiras como Cecropia palmata, Henriettea succosa, Miconia hypoleuca e Miconia tomentosa. Predominaram plântulas com germinação epígeas, cotilédones foliáceos e fanerocotiledonares, as quais tem facilidade de estabelecimento em áreas mais abertas. Palavras-chave: chuva de sementes, fanerocotiledonar, regeneração natural.
\end{abstract}

\begin{abstract}
The aim of this study was to evaluate the identification and floristic composition of seedlings of tree species, located in the soil seed bank of a remnant of the Dense Ombrophilous Forest of the Lowlands, in the Northeast of Brazil, from a morphofunctional ecology standpoint. A hundred and fifty two soil samples $(0.2$ $\mathrm{m} \times 0.15 \mathrm{~m} \times 0.05 \mathrm{~m}$ ) were taken from a forest remnant, stored in polyethylene bags, identified and then taken to the Forest Nursery at the Federal Rural University of Pernambuco, where they were placed in polyethylene boxes under a $70 \%$ shade cloth and evaluated daily for a period of seven months. The seedlings emerged were photographed, separated into morphospecies, identified at the family and gender level and, when possible, at the species level. The density and absolute frequency, as well as the successional and morphological classification of the seedling cotyledons were estimated. In total, 1,577 seedlings of 31 morphospecies were cataloged. Melastomataceae was the family that presented the greatest richness, representing $48 \%$ of the species identified. The average density was 344.62 seeds. $\mathrm{m}^{-2}$, with higher densities for species of the family Melastomataceae, together with Maprounea guianensis and Cecropia palmata. There was a predominance of seedlings with epigeal and phanerocotylar germination, and with foliaceous cotyledons, corresponding to 93.56\%. The seed bank was composed, predominantly, by pioneer species such as Cecropia palmata, Henriettea succosa, Miconia hypoleuca and Miconia tomentosa. Seedlings with epigeal germination, foliaceous and phanerocotylar cotyledons predominated for being easily established in more open areas.

Keywords: seed rain, phanerocotylar, natural regeneration.
\end{abstract}

\section{INTRODUCTION}

Morphofunctional ecology seeks to understand the functions of morphological structures that assist in the development and initial establishment of seedlings and in the complex succession process of plant communities (RESSEL et al., 2004; GOGOSZ; BOEGER, 2019). Thus, filling knowledge gaps about it can contribute to ecological studies. 
Studies have suggested that the variation in the characteristics of the cotyledons of the seedlings in terms of position, epigeal and hypogeal; texture or function, foliaceous or photosynthetic and nutrient reserve storage; and exposure, phanerocotylar and cryptocotylar may require different establishment strategies between species (RESSEL et al., 2004; GARWOOD, 2009; MENEZES et al., 2018).

In Brazil, more and more studies classifying the morphofunctional ecology of seedlings of tree species occurring in the Cerrado, in the Atlantic Forest, in the Amazon Forest and in the Caatinga have been carried out, showing a predominance of seedlings with epigeal germination and foliaceous and phanerocotylar cotyledons (RESSEL et al., 2004; CAMARGO et al., 2008; ALVES et al., 2016; MENEZES et al., 2018). These seedlings usually develop from small seeds, have rapid development and colonization and are found in open areas and in the early stages of succession (GOGOSZ et al., 2015; GOGOSZ; BOEGER, 2019).

Although the seedling stage represents one of the most critical phases in the life cycle of a plant (GARWOOD, 2009), it is in this initial phase that the morphological characteristics can assist in the knowledge of the regenerative processes of forests such as the seed and seedling bank.

The soil seed bank is formed by all viable seeds present in the soil and in the litterfall layer. They arrive through different dispersing agents and are incorporated into the soil, where they can remain viable for months and even years, until the emergence of favorable conditions to germinate, form the seedling bank and, later, take the place of the adult individual (SIMPSON; LECK; PARKER, 1989). Thus, its assessment allows us to conclude which species have initial potential for colonization in the area.

In Atlantic Forest areas, the seed bank species richness has been varied, considering that there may be a greater seeds inflow to compose the seed bank than an outflow to form the seedling bank (CORREIA; MARTINS, 2015; KUNZ; MARTINS, 2016; SILVA et al., 2018; SILVA et al., 2019). Thus, it is necessary to know the species autoecological aspects in the initial stages, since the heterogeneity existing in the environment and the plants responses to abiotic and biotic factors result in different ecological niches (GOGOSZ; BOEGER, 2019).

Therefore, the aim of this study was to evaluate the identification and floristic composition of seedlings of tree species, located in the soil seed bank of a remnant of the Dense Ombrophilous Forest of the Lowlands, in the Northeast of Brazil, from a morphofunctional ecology standpoint.

\section{MATERIALS AND METHODS}

\section{Data collection area}

Soil samples for seed bank evaluation were collected from a remnant of the Dense Ombrophilous Forest of the Lowlands (IBGE, 2012), located in the municipality of Sirinhaém, State of Pernambuco, Brazil. The remnant has an approximate area of 44 ha and is located on land belonging to Usina Trapiche S/A., under geographic coordinates $8^{\circ} 33^{\prime} 4.77^{\prime \prime} \mathrm{S}$ and $35^{\circ} 8^{\prime} 51.72^{\prime \prime} \mathrm{W}$.

The region has a monsoon climate (Am) according to the Köppen classification (ALVARES et al., 2013), with the rainiest period between May and July, and the hottest and driest period from September to December, with rainfall and mean annual temperature (1980 to 2018) of 2,000 mm and $27{ }^{\circ} \mathrm{C}$, respectively (APAC, 2019).

The predominant soils in the study region are of the type Yellow Latosol; Yellow Argisol; Red-Yellow Argisol; Grayish Argisol; Gleysol; Cambisol and Fluvic Neosol (SANTOS et al., 2018).

\section{Soil sample collection}

The seed bank was evaluated using 152 soil samples removed with the aid of a gardening spade, a hoe and a frame used to delineate the area, measuring $20 \mathrm{~cm} \mathrm{x} 15 \mathrm{~cm} \times 5 \mathrm{~cm}$ (length, width and depth) totaling 4.56 $\mathrm{m}^{2}$.

For soil sample removal, 38 subplots of $1 \mathrm{~m}^{2}$ were delimited inside the 38 plots, installed along three transects to evaluate the arboreal component of the study area (LIMA et al., 2019). The soil samples were taken $50 \mathrm{~cm}$ from the vertices of these subplots. Thus, each set of four samples was approximately $65 \mathrm{~m}$ away from the next set (Figure 1). Leaves and dry branches not yet decomposed were removed, and the soil samples for the seed bank evaluation were considered soil and litterfall, depending on the plot, since there were plots in which the soil was fully exposed.

The collection was carried out in the third week of September 2018. The samples were stored in polyethylene bags, identified with the number of each plot; then, they were taken to the Forest Nursery of the Department of Forestry Science (DCFL) of the Federal Rural University of Pernambuco, (UFRPE), Recife-PE, where they were placed in polyethylene boxes, without the presence of substrate, with the same dimensions as the frame used to delimit the soil, $20 \mathrm{~cm} \times 15 \mathrm{~cm} \times 5 \mathrm{~cm}$ (length, width and depth), randomly arranged in the seedbed to ensure the same conditions for all samples and covered with a $70 \%$ shade cloth to facilitate germination, as proposed by Silva et al. (2019). 
Along with the soil samples, containers with washed and sterilized sand were randomly placed in an oven at $105^{\circ} \mathrm{C}$ for two hours, to evaluate possible seed rain contamination. The samples were manually watered with the aid of a watering can, twice a day, except on rainy days.

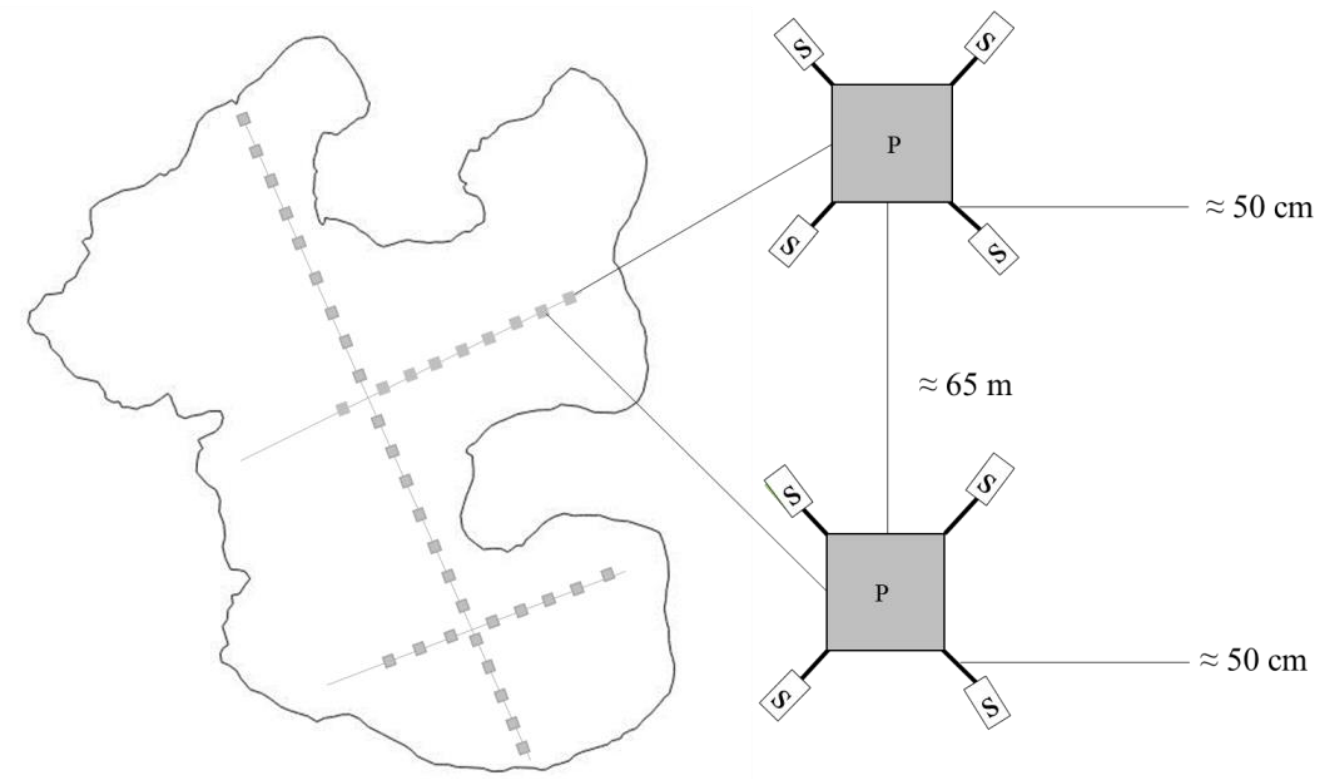

Figure 1. Sketch of soil samples removal for evaluation of the soil seed bank of a remnant of the Dense Ombrophilous Forest of the Lowlands, in the Northeast of Brazil. Where: $\mathrm{p}=$ subplot with $1 \mathrm{~m}^{2} ; \mathrm{s}=$ soil samples taken.

Figura 1. Croqui da retirada das amostras de solo para avaliação do banco de sementes do solo de um remanescente de Floresta Ombrófila Densa das Baixas, Nordeste do Brasil. Em que: p= subparcela com $1 \mathrm{~m}^{2} ; \mathrm{s}=$ amostras de solo retiradas.

After 130 days of the experiment installation and after five days without the emergence of new seedlings, all the emerging seedlings were removed and some specimens of each morphospecies were transplanted into polyethylene bags, with a capacity of $1.0 \mathrm{~kg}$, or containers with a capacity of $500 \mathrm{~g}$, so they could develop, and then a reliable identification could be made.

Melastomataceae seedlings were placed in small containers, with a capacity of $50 \mathrm{~g}$ or $100 \mathrm{~g}$, and later transplanted into larger containers, until the development of morphological characteristics that could differentiate them at the species level. The substrate used in all containers was forest soil, removed from the same remnant, and medium vermiculite (ratio 2:1).

After removing all the seedlings, the soil was turned over, so that the seeds that might be at the bottom of the soil could be closer to the surface and facilitate their germination. The seed bank was evaluated daily for a period of seven months (end of September to end of April), using the seedling emergence method.

During soil collection and monthly visits to the study area in the following months, shrub and arboreal individuals were observed to verify the occurrence of flowering and fruiting. Botanical material was removed from individuals that presented flowers and fruits. This material was properly herborized, identified by comparison with exsiccates in the Sérgio Tavares Herbarium (HST), at the Department of Forestry Science of the Federal Rural University of Pernambuco, and by specialists.

When species bore fruit, the fruits were collected and processed and the seeds were put to germinate in trays containing vermiculite as substrate and then placed inside the greenhouse in the Forest Nursery. Thus, with seed germination and seedling growth, it was possible to identify the seedlings that emerged in the seed bank.

\section{Seedling definition and data analysis}

The concept of seedling is varied and there is no precise definition, since different authors can take into account physiological and ecological aspects. Thus, it is known that a seedling appears when a seed germinates, but its complete formation is not fully defined, causing some authors to consider the individual as a seedling, while depending on the seed reserves, if a portion of the biomass comes from the seed reserves, or even when it presents some functional structure originating from seed reserves (MELO et al., 2004; CAMARGO et al., 2008). However, under natural conditions, this differentiation is not possible due to the different morphological characteristics presented by the species and by the capacity to capture resources. Thus, in the present study, 
individuals were considered as seedlings after the emission and full expansion of the eophyll, as proposed in the works by Gogosz et al. (2015), Gogosz and Boeger (2019) and Silva et al. (2019).

The seedlings that emerged in the seed bank were enumerated, and the number, morphospecies, and morphology of the cotyledons were noted in a spreadsheet, and the seedlings were then photographed. Subsequently, they were separated into morphospecies, identified at family level, genus and, when possible, at species level with their scientific name and respective authors, and updated according to the Missouri Botanical Garden database, by the website www.tropicos.org, according to the Angiosperm Phylogeny Group IV (APG IV) classification system.

The emergence speed was obtained with the weekly count of the number of emerged seedlings. The following phytosociological parameters were estimated for each species identified in the seed bank: absolute density (AD), relative density (RD), absolute frequency (AF) and relative frequency (RF), described by MuellerDombois and Ellenberg (1974). The data were processed using the software Microsoft Excel for Windows ${ }^{\mathrm{TM}}$ 2016.

The seedlings identified were classified according to the successional classification following the methodology proposed by Gandolfi et al. (1995), who consider three main groups: pioneer species, early secondary and late secondary, in addition to unclassified species that do not fit into any of these three groups, either because of lack of studies or for being identified only as morphospecies. The successional classification was performed through observations of adult tree species identified in the field and in the study by Lima et al. (2019) developed in the study area and also by bibliographic research.

The functional morphology of seedling cotyledons was analyzed as proposed by Garwood (2009), who considers the hypocotyl elongation as epigeal $(\mathrm{E})$ or hypogeal $(\mathrm{H})$; the cotyledons exposure, as cryptocotylar $(\mathrm{C})$ or phanerocotylar $(\mathrm{P})$; and the texture, as foliaceous $(\mathrm{F})$ and reserve $(\mathrm{R})$, which function as photosynthesizers and nutrient reserve storages, respectively, resulting in seedlings with the following combinations PEF, PER, PHF, PHR, CER, CEF, CHR and CHF .

\section{RESULTS}

During the observation period, 1,577 seedlings belonging to 13 botanical families were recorded. Seeds germinated from a total of 31 morphospecies, 24 being identified at a specific level, 4 at a generic level and 3 could not be classified at any taxonomic level (Table 1), as they did not present morphological characteristics for comparison with adult individuals and possible identification.

Table 1. Floristic composition and morphofunctional ecology classification of seedlings of tree species emerged in the soil seed bank of a remnant of the Dense Ombrophilous Forest of the Lowlands, in the Northeast of Brazil.

Tabela 1. Florística e classificação da ecologia morfofuncional de plântulas de espécies arbóreas emergidas no banco de sementes do solo de um remanescente de Floresta Ombrófila Densa das Terras Baixas, Nordeste do Brasil.

\begin{tabular}{|c|c|c|c|c|c|c|c|}
\hline Family/Species & $\mathrm{N}_{\mathrm{i}}$ & EG & MEC & $\mathrm{AD}_{\mathrm{i}}$ & $\mathrm{RD}_{\mathrm{i}}$ & $\mathrm{AF}_{\mathrm{i}}$ & $\mathrm{RF}_{\mathrm{i}}$ \\
\hline \multicolumn{8}{|l|}{ Annonaceae } \\
\hline Guatteria pogonopus Mart. & 3 & Es & PEF & 0.69 & 0.19 & 1.97 & 0.41 \\
\hline \multicolumn{8}{|l|}{ Araliaceae } \\
\hline Schefflera morototoni (Aubl.) Maguire et al. & 37 & Es & PEF & 8.51 & 2.35 & 7.89 & 1.62 \\
\hline \multicolumn{8}{|l|}{ Cannabaceae } \\
\hline Trema micrantha (L.) Blume & 1 & $\mathrm{Pi}$ & PEF & 0.23 & 0.06 & 0.66 & 0.14 \\
\hline Family/Species & $\mathrm{N}_{\mathrm{i}}$ & EG & MEC & $\mathrm{AD}_{\mathrm{i}}$ & $\mathrm{RD}_{\mathrm{i}}$ & $\mathrm{AF}_{\mathrm{i}}$ & $\mathrm{RF}_{\mathrm{i}}$ \\
\hline \multicolumn{8}{|l|}{ Euphorbiaceae } \\
\hline \multicolumn{8}{|l|}{ Fabaceae } \\
\hline Bowdichia virgilioides Kunth & 1 & Ls & PEF & 0.23 & 0.06 & 0.66 & 0.14 \\
\hline \multicolumn{8}{|l|}{ Hypericaceae } \\
\hline Vismia guianensis (Aubl.) Choisy & 18 & $\mathrm{Pi}$ & PEF & 4.14 & 1.14 & 11.18 & 2.30 \\
\hline Malpighiaceae & & & & & & & \\
\hline
\end{tabular}

FLORESTA, Curitiba, PR, v. 51, n. 3, p. 614-622, jul/set 2021.

Silva, J. P. G. et.al.

ISSN eletrônico 1982-4688

DOI: $10.5380 /$ rf.v51 i3. 71553 
Continuation...

Byrsonima sericea DC.

Melastomataceae

Henriettea succosa (Aubl.) DC.

Miconia affinis DC

Miconia caiuia E.C.O. Chagas \& R. Goldenb.

Miconia ciliata (Rich.) DC.

Miconia cf. cinnamomifolia (DC.) Naudin

Miconia holosericea (L.) DC.

Miconia hypoleuca (Benth.) Triana

Miconia prasina D.C.

Miconia cf. pyrifolia Naudin

Miconia tomentosa (Rich.) D. Don ex DC.

Miconia minutiflora (Bonpl.) DC.

Miconia sp. $1 *$

Miconia sp. 2

Miconia sp. 3

Miconia sp. 4

Miconia sp. 5

Moraceae

Helicostylis tomentosa (Poepp. \& Endl.) Rusby

Peraceae

Pera glabrata (Schott) Poepp. ex Baill.

Pogonophora schomburgkiana Miers ex Benth.

Polygonaceae

Coccoloba parimensis Benth.

Salicaceae

Casearia javitensis Kuntha

Urticaceae

Cecropia palmata Willd.

1

$\begin{array}{llllll}\text { Pi } & \text { PEF } & 0.23 & 0.06 & 0.66 & 0.14\end{array}$

$\begin{array}{llllll}\text { Pi } & \text { PEF } & 38.16 & 10.53 & 55.92 & 11.49\end{array}$

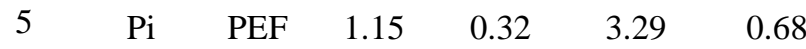

$1 \quad$ Es

$1 \quad \mathrm{Pi}$

PEF

$0.23 \quad 0.06$

0.66

0.14

2

Pi PEF

$0.23 \quad 0.06$

0.66

0.14

70

Es

PEF

$0.46 \quad 0.13$

1.32

0.27

158

PEF

16.06

4.44

34.87

7.16

158

62

48

$\mathrm{Pi}$

PEF

36.32

10.02

41.45

8.51

289

Es

PEF 14.25

3.93

26.97

5.54

PEF 11.03

3.04

23.03

4.73

29

367

Pi

PEF 66.44

18.33

58.55

12.03

PEF

6.67

1.84

14.47

2.97$$
\text { - } 84.37
$$

23.27

70.39

14.46

$\begin{array}{lll} & \text { PEF } 0.23 \quad 0.06\end{array}$

0.66

0.14

32

3

PEF

2.99

0.82

7.89

1.62

PEF

7.36

2.03

12.50

2.57

PEF 0.69

0.19

1.97

0.41

Morfoespécie

Morphospecies 1

6

Ls

CHR

1.38

0.38

1.97

0.41

4 Es

$\begin{array}{lll}\text { PEF } & 0.92 \quad 0.25\end{array}$

2.63

0.54

10

Es

PEF

$2.30 \quad 0.63$

2.63

0.54

Morphospecies 2

$$
5
$$

Es

PEF

1.15

0.32

3.29

0.68

3

Es

PEF

0.69

0.19

1.97

0.41

Pi

PEF

32.18

8.88

52.63

10.81

Morphospecies 3

$17 \quad$ - $\quad$ PEF $3.91 \quad 1.08 \quad 8.55 \quad 1.76$

Total

1.577

PEF 0.46

0.13

Where: $\mathrm{N}_{\mathrm{i}}=$ Number of individuals; MEC = Morphofunctional Ecology of Cotyledons; PEF = Seedling with epigeal, phanerocotylar 1.577

$-\quad 0.23$

0.06

0.66
germination and foliaceous cotyledons; $\mathrm{CHR}=$ Seedling with hypogeal, cryptocotylar germination, and reserve cotyledons. EG $=$ Ecological Group; $\mathrm{Pi}=$ Pioneers; Es = Early secondary; Ls = Late secondary; $\mathrm{AD} i=$ Absolute density of the species $i$ (seedlings. $\mathrm{m}^{2}$ ); RD $i=$ Relative density of the species $i$, AF $i=$ Absolute frequency of the species $i$, RF $i=$ Relative frequency of the species $i$.

${ }^{1}$ In Miconia sp.1 are all species and individuals that were identified at the genus level but died before confirmation at the species level.

Melastomataceae was the family presenting the highest richness with $48 \%$ of the species identified, and $79 \%$ of the seedlings emerged.

The emergence of tree species started three weeks after the installation of the experiment with the species Trema micranta and Maprounea guianensis; later, in the fourth week, the species Cecropia palmata, Trema micrantha, Maprounea guianensis, Henriettea succosa, Miconia cf. pyrifolia and Miconia minutiflora emerged. The species Miconia spp. and Henriettea succosa were constant, emerging throughout the evaluation of the bank. The greatest seedling emergence occurred in the 18th, 25th, 26th and 29th week (Figure 2), causing

FLORESTA, Curitiba, PR, v. 51, n. 3, p. 614-622, jul/set 2021. 
an emergence speed of 6.56, 4.68, 4.50, 5.69 seedlings/week, in the respective weeks. The species Henrietteia succosa, Miconia tomentosa and Miconia hypoleuca were the most common ones.

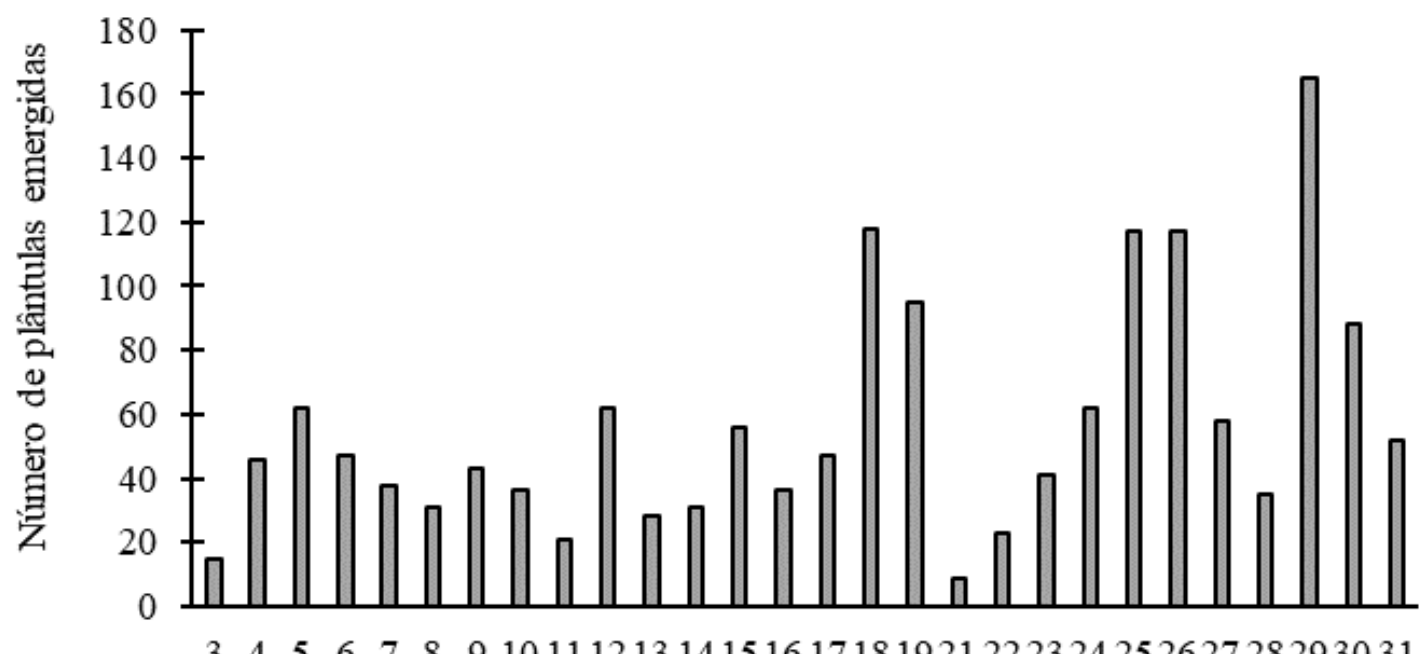

\section{Semanas após a instalação do experimento}

Figure 2. Number of seedlings emerged in the seed bank of a remnant of the Dense Ombrophilous Forest of the Lowlands, in the Northeast of Brazil.

Figura 2. Número de plântulas emergidas no banco de sementes de um remanescente de Floresta Ombrófila densa das Terras Baixas, Nordeste do Brasil

The mean density was $344.62 \pm 41.18$ seeds. $\mathrm{m}^{-2}$ with higher values for the species Miconia tomentosa, Henriettea succosa, Miconia hypoleuca, Maprounea guianensis and Cecropia palmata. Cecropia palmata, Miconia tomentosa and Henriettea succosa were the most frequent (frequency > 50\%).

In the successional classification, there was a predominance of pioneer and early secondary species with $35.48 \%$ each, followed by late secondary species with $6.45 \%$, whereas $22.59 \%$ of the species were left unclassified because they were not identified at a specific level. Bowdichia virgilioides and Helicostylis tomentosa were the only late secondary species found in the present study.

Regarding the functional morphology of cotyledons, $93.56 \%$ of the species are seedlings with epigeal, phanerocotylar germination and foliaceous cotyledons (PEF), with predominance of Henriettea succosa, Miconia tomentosa and Cecropia palmata. Helicostylis tomentosa was the only species with hypogeal, cryptocotylar germination, and reserve cotyledons (CHR), emerging between the 7th and 21st week.

Table 2. Proportion of species and number of seedlings emerged in the seed bank, classified according to a morphofunctional ecology of cotyledons, in a remnant of the Dense Ombrophilous Forest of the Lowlands, in the Northeast of Brazil.

Tabela 2. Proporção de espécies e de plântulas emergidas no banco de sementes e classificadas de acordo com a ecologia morfofuncional dos cotilédones, remanescente de Floresta Ombrófila Densa das Terras Baixas, Nordeste do Brasil

\begin{tabular}{cccc}
\hline & \multicolumn{3}{c}{ Morphofunctional Ecology of Cotyledon } \\
\cline { 2 - 4 } & PEF & CHR & ND \\
\hline Number of Species & $93.56 \%$ & $3.22 \%$ & $3.22 \%$ \\
Number of Individuals & $99.56 \%$ & 0.38 & 0.06 \\
\hline
\end{tabular}

Where: PEF = Seedling with epigeal, phanerocotylar germination and foliaceous cotyledons; CHR = Seedling with hypogeal, cryptocotylar germination, and reserve cotyledons, $\mathrm{ND}=$ no discrimination, differentiation was not possible.

\section{DISCUSSION}

The richness of species found in this study has been higher than those found by some authors evaluating the seed bank in the Dense Ombrophilous Forest of the Lowlands (CORREIA; MARTINS, 2015; SILVA et al., 2019). This difference may be related to the morphological and physiological characteristics of the seeds present

FLORESTA, Curitiba, PR, v. 51, n. 3, p. 614-622, jul/set 2021.

Silva, J. P. G. et.al.

ISSN eletrônico 1982-4688

DOI: $10.5380 /$ rf.v51 i3. 71553 
in the bank, the place and time of soil collection for evaluation, the established vegetation and the forest age (BAIDER et al., 2001).

The family with the greatest richness was Melastomataceae. The high representation of Melastomataceae, especially Miconia, has also been found in other studies evaluating soil seed banks (FIGUEIREDO et al., 2014; SILVA et al., 2019), partly reflecting the influence of the established vegetation, since Melastomataceae was one of the families with the highest species richness in the floristic survey and phytosociological analysis of the adult tree vegetation in the study area (LIMA et al., 2019).

The predominance of species of the Melastomataceae family in the seed bank is also related to the characteristics of their respective fruits and seeds. Its fleshy fruits serve as food for birds, and are easily dispersed by small birds and bats (GALETTI et al., 2013), and have small seeds ( $<5 \mathrm{~mm}$ in length); when they are not in the litterfall layer, they can easily penetrate the soil to become part of the seed bank (SILVA et al., 2018), and when they fall into exposed soil, they manage to germinate and become part of the seedling bank.

Regarding seedling emergence, Trema micrantha and Maprounea guianensis began to appear in the third week after the installation of the experiment, and Cecropia palmata, Henriettea succosa, Miconia cf. Pyrifolia and Miconia minutiflora started to appear in the fourth week. It is possible to infer that in forest dynamics such as the opening of a clearing and modification of the soil structure, these would be the first tree species that would appear, with the greatest emergence of their seedlings occurring in the 18th week after the modification, differing from the results of Silva et al. (2019). The authors evaluated the soil seed bank of a remnant of the Dense Ombrophilous Forest of the Lowlands in Pernambuco, and observed an early emergence in the first week with seedlings of Albizia pedicellaris (DC.) L. Rico and in the second week Trema micrantha. The same authors observed the highest emergence in the 8th week with 411 seedlings emerging and in the 26th week with 554 and an emergence speed of 51.4 and 21.3 seedlings/week, in the respective weeks. With the diversity of seeds existing in the seed bank, they need adequate environmental conditions and time for their germination to occur, thus causing a variable seedling emergence time.

Among the seedlings that were identified at a specific level, Trema micrantha and Miconia holosericea were the species that were not part of the sampling of the floristic composition of the study area arboreal component (LIMA et al., 2019). In Brazil, Trema micrantha commonly occurs as an abundant species in the seed bank (CORREIRA; MARTINS, 2015; SILVA et al., 2019). As it is a species with small fruits and zoochoric dispersion, its seeds may have been brought from areas close to the forest remnant. Although not sampled among tree species, Miconia holosericea was present in several adult and regenerating individuals within the remnant.

The average seed density of tree species has been diverse in different forest ecosystems. In the Dense Ombrophilous Forest of the Lowlands in Pernambuco, Silva et al. (2019) found $458.8( \pm 98.82)$ seeds.m ${ }^{-2}$ with better representation of Miconia prasina, Cecropia pachystachya Trécul, Miconia cf. hypoleuca and Miconia affinis. Correia and Martins (2015) found 222.59 seeds.m ${ }^{-2}$ in a remnant of a fragment of the Dense Ombrophilous Forest of the Lowlands in Espírito Santo, with a greater representation of Trema micrantha and Cecropia pachystachya. This difference in density between forest remnants is greatly influenced by the number of adult reproductive individuals, time of soil collection, as well as the conservation of the remnant. Areas in early or medium stages have a higher seed bank density, as demonstrated in a study carried out by Baider et al. (2001), in remnants of the Atlantic Forest, São Paulo.

In the successional classification, there was a predominance of pioneer and early secondary species. Pioneer and early secondary species have commonly predominated in the seed bank (KUNZ; MARTINS, 2016; SILVA et al., 2019). The predominance of pioneer species may be related to the characteristics of the seeds, mainly because they are small (GOGOSZ et al., 2015), they can penetrate the litterfall and the soil when dispersed.

Bowdichia virgilioides and Helicostylis tomentosa were the late secondary species found in the present study. The former has its seeds dispersed in the fruit, which, when reaching the ground, acts as a protector for the seeds, hindering their germination. Over time, these seeds penetrate the litterfall or are covered by newly fallen leaves. Because they are small seeds and with physical dormancy, they probably manage to remain in viable soil for a long time. On the other hand, Helicostylis tomentosa seeds have physical and physiological dormancy (CAMARGO et al., 2008), and although it is not a species commonly found in the seed bank, its presence may be related to the period of its dispersion, which occurred with intensity three months before the soil collection.

Regarding the functional morphology of the seedlings cotyledons, there was a predominance of seedlings with epigeal, phanerocotylar germination and with foliaceous cotyledons (PEF). The morphofunctional type PEF is often the most frequent, reaching $56 \%$ of the total species identified in some forest remnants (RESSEL et al., 2004; MENEZES et al., 2018), but others show a predominance of seedlings with reserve cotyledons, being distributed in seedlings with epigeal and phanerocotylar germination (PER), and with

FLORESTA, Curitiba, PR, v. 51, n. 3, p. 614-622, jul/set 2021.

Silva, J. P. G. et.al.

ISSN eletrônico 1982-4688

DOI: $10.5380 /$ rf.v51 i3. 71553 
hypogeal and cryptocotylar germination (CHR) (BARALOTO; FORGET, 2007; ALVES et al., 2016). This difference may be related to the conservation of the remnants and the number of species sampled.

Seedlings with epigeal germination and foliaceous cotyledons usually develop from small seeds, have rapid development after germination, and reserve cotyledons seedlings come from larger seeds, with a greater amount of reserve and slow development (BARALOTO; FORGET, 2007; GOGOSZ; BOERGER, 2019).

Smaller seeds commonly come from pioneer species, dispersed by the wind or in their fruits by small birds and bats (GALETTI et al., 2013), or they can be secondarily dispersed by ants (SILVEIRA et al., 2013); because they are small, they easily penetrate the litterfall and the soil to compose the seed bank (SILVA et al., 2018). Seedlings with reserve cotyledons, on the other hand, come from larger seeds and depend on larger animals to be dispersed and are likely to establish themselves in the seedling bank of better conserved forest remnants (BARALOTO; FORGET, 2007; GALETTI et al., 2013). Thus, as they come from small seeds, PEF seedlings have an advantage in dispersion and start using the light resource earlier because of foliaceous and photosynthetic cotyledons, which may justify their predominance in the seed bank.

Helicostylis tomentosa was the only seedling with hypogeal and cryptocotylar germination and reserve cotyledons identified in the present study. As an adult, it is a late secondary species (LIMA et al., 2019) and it is abundant in the seedling bank in the study area. Cryptocotylar and hypogeal seedlings keep the reserve cotyledons protected, which could be more advantageous for these seedlings in natural conditions within the forest, being able to use the reserves during the establishment phase. Thus, information on the floristic composition and functional morphology of the cotyledons of the seedlings present in the seed bank helps to understand species initial establishment in a given habitat and demonstrates new species emergence capacity to increase the seedling bank richness in the occurrence of changes in the forest structure.

\section{CONCLUSIONS}

With the evaluation of the seed bank, it was possible to conclude that:

- The seed bank was predominantly composed of pioneer species such as Cecropia palmata, Henriettea succosa, Miconia hypoleuca and Miconia tomentosa.

- There was a predominance of seedlings with epigeal germination and with foliaceus and phanerocotylar cotyledons, which are easy to establish in more open areas.

\section{ACKNOWLEDGEMENT}

The authors would like to thank the Coordenação de Aperfeiçoamento de Pessoal de Nível Superior (Capes) - Finance Code 001, for granting a PhD scholarship to the first author, and to Usina Trapiche S/A. for enabling access to the study area, logistical support and availability of its workers to aid the researchers during field activities.

\section{REFERENCES}

ALVARES, C. A.; STAPE, J. L.; SENTELHAS, P. C.; DE MORAES GONÇALVES, J. L.; SPAROVEK, G. Koppen's climate classification map for Brazil. Meteorologische Zeitschrift, Berlin v. 22, n. 6, p. 711-728, 2013.

ALVES, M. C. J. L.; MEDEIROS, D. P. W.; POMPELI, M.; ZICKEL, C. S. Morphofunctional Characteristics of Seedlings of 30 Woody Species from a Tropical Coastal Vegetation (Restinga Forest), Area of Northeastern Brazil. International Journal of Ecology and Environmental Sciences, Jaipur, v. 42, n. 4, p. 257-264, 2016.

AGÊNCIA PERNAMBUCANA DE ÁGUAS E CLIMA (APAC). Disponível em: <http://www.apac.pe.gov.br/meteorologia/monitoramento-pluvio.php>. Acesso em: 30 dez. 2019.

BARALOTO C.; FORGET P. M. Seed size, seedling morphology, and response to deep shade and damage in neotropical rain forest trees. American Journal of Botany, Lancaster, v.94, n.6, p.901-911. 2007.

BAIDER, C.; TABARELLI, M.; MANTOVANI, W. The soil seed bank during Atlantic Forest regeneration in southeast Brazil. Revista Brasileira de Biologia, Rio de Janeiro, v. 61, n. 1, p. 35-44, 2001.

CAMARGO, J. L. C.; FERRAZ, I. D. K.; MESQUITA, M. R.; SANTOS, B. A.; BRUM, H. D. Guia de Propágulos e Plântulas da Amazônia. Manaus: Editora INPA, 2008. 168p.

CORREIA, G. G. S.; MARTINS, S. M. Banco de Sementes do Solo de Floresta Restaurada, Reserva Natural Vale, ES. Floresta e Ambiente, Seropédica, v. 22, n. 1, p. 79-87. 2015.

FLORESTA, Curitiba, PR, v. 51, n. 3, p. 614-622, jul/set 2021.

Silva, J. P. G. et.al. 
FIGUEIREDO, P. H. A.; MIRANDA, C. C., ARAUJO, F. M.; VALCARCEL, R. Germinação ex-situ do banco de sementes do solo de capoeira em restauração florestal espontânea a partir do manejo do sombreamento. Scientia Forestalis, Piracicaba, v. 42, n. 101, p. 69-80, 2014.

GALETTI, M.; GUEVARA, R.; CÔRTES, M. C.; FADINI, R.; MATTER, S. V.; LEITE, A. B.; LABECCA, F.; RIBEIRO, T.; CARVAlHO, C. S.; COLleVATTI, R. G.; PIRES, M. M.; GUIMARÃES JR; P. R.; BRANCALION, P. H.; RIBEIRO, M. C.; JORDANO, P. Functional extinction of birds drives rapid evolutionary changes in seed size. Science, Washington v. 340, n. 6136, p. 1086-1090, 2013.

GANDOLFI, S.; LEITÃO FILHO, H. F. BEZERRA, C. L. F. Levantamento florístico e caráter sucessional das espécies arbustivo-arbóreas de uma Floresta Mesófila Semidecídua no município de Guarulhos, SP. Revista Brasileira de Biologia, Rio de Janeiro, v. 55, n. 4, p. 753-767, 1995.

GARWOOD, N. C. Seedlings of Barro Colorado Island and the neotropics. Cornell University Press, New York, NY, US. 2009. 656 p.

GOGOSZ, A. M.; BOEGER, M. R. T. Functional morphology of subtropical tree seedlings in southern Brazil, Rodriguésia, Rio de Janeiro, v. 70, p. 1-12,2019.

GOGOSZ, A. M.; BOEGER, M. R. T.; COSMO, N. L.; NOGUEIRA, A. C. Morfologia de diásporos e plântulas de espécies arbóreas da floresta com araucária, no Sul do Brasil. Floresta, Curitiba, v. 45, n. 4, p. 819 - 832 , 2015.

INSTITUTO BRASILEIRO DE GEOGRAFIA E ESTATÍSTICA (IBGE). Manual técnico da vegetação brasileira. Rio de Janeiro: CDDI; IBGE, 2012. 271 p. (Série Manuais Técnicos em Geociências, n. 1).

KUNZ, S. H.; MARTINS, S. V. Soil seed bank in seasonal semideciduous forest and abandoned pasture. Revista Árvore, Viçosa-MG, v. 40, n. 6, p. 991-1001, 2016.

LiMA, R. B. A.; MARANGON, L. C.; FREIRE, F. J.; FELICIANO, A. L.; SILVA, R. K. S. Structure and diversity in Ombrophilous Forest in the Zona da Mata of Pernambuco. Floresta Ambiente, Seropédica. v.26, n.2, 2019.

MElO, F. P. L.; AGUIAR NETO, A. V.; SiMABUKURO, E. A.; TABARELLI, M. Recrutamento de estabelecimento de plântulas In: FERREIRA, A. G.; BORGHETTI, F. (Ed.). Germinação: do básico ao aplicado. Ed. Artimed, 2004. 237-250p.

MENEZES, T. G. C.; RODAL, M. J. N.; LIMA, A. L. A.; LIMA, L. R.; PINTO, M. A. D. S. C.; LEMO, A. L. Do seedling functional groups reflect ecological strategies of woody plant species in Caatinga? Acta Botanica Brasilica, Porto Alegre, v. 32, n.1, p. 20-27. 2018.

MUELLER DOMBOIS, D.; ELLENBERG, H. Aims and methods of vegetation ecology. New York: John Wiley and Sons, 1974. 547 p.

RESSEL, K, GUILHERME, F. A. G, SCHIAVINI, I. Ecologia morfofuncional de plântulas de espécies arbóreas da Estação Ecológica do Panga, Uberlândia, Minas Gerais. Revista Brasileira de Botânica, São Paulo, v. 27, n.2 p.311-323. 2004.

SANTOS, H. G. dos; JACOMINE, P. K. T.; ANJOS, L. H. C. dos; OLIVEIRA, V. Á. de; LUMBRERAS, J. F.; COELHO, M. R.; ALMEIDA, J. A. de; ARAÚJO FILHO, J. C. de; OLIVEIRA, J. B. de; CUNHA, T. J. F.; EMBRAPA SOLOS. Sistema Brasileiro de Classificação de Solos. 5 ed. Brasília, DF: Embrapa, 2018,356 p.

Silva, J. P. G.; MARANGON, L. C.; FELICIANO, A. L. P.; FERREIRA, R. L. C. Chuva de sementes e estabelecimento de plântulas em floresta tropical na região Nordeste do Brasil. Ciência Florestal, Santa Maria, v. 28, n. 4, p. 1478-1490, 2018.

Silva J. P. G.; MARANGON, L. C.; FEliCIANO, A. L. P.; FERREIRA, R. L. C.; SANTOS, W. B.; TORRES, J. E. L. Soil Seed Bank in the Tropical Rainforest Inserted in Agricultural Matrix, Northeast Region of Brazil. Journal of Experimental Agriculture International, v.30, n.4, p. 1-11, 2019.

SILVEIRA, F. A. O.; FERNANDES, G. W.; LEMOS-FILHO, J. P. Seed and Seedling Ecophysiology of Neotropical Melastomataceae: Implications for Conservation and restoration of Savannas and Rainforests. Annals of the Missouri Botanical Garden, Saint Louis, v. 99, n. 1, p. 82-93, 2013.

SIMPSON, R. L.; LECK, M. A.; PARKER, V. T. Seed banks: General concepts and methodological issues. In: LECK, M. A.; PARKER, V. T.; SIMPSON, R. L. Ecology of soil seed banks. Londres: Academic Press, 1989. Cap. 1, p. 3-8. 